Monika Sadowska

UnIWERSYTET ŚLĄSKI W KaTOWICACH

\title{
Lęk jako tabu nowoczesności - wariantowość tekstów filmowych
}

\author{
Jeżeli ekran będzie dostatecznie mroczny, \\ oczyma duszy odczytamy wszystko, co trzeba. \\ V. Lewton ${ }^{1}$
}

Jak stwierdza Agata Bielik-Robson: „Pod językową kliszą "świata otwartych możliwości”, jaką żmudnie wypracowała nowoczesność, jednostka przeczuwa [...] świat chaosu, dezorientacji, bezradności, absurdu"2. Rzeczy, które do tej pory traktowaliśmy jako constans, zmieniły swoje przeznaczenie i charakter. Przedmioty uległy przekształceniu w obrazy, których nie można posiąść i które wymykaja się wymianie, której wcześniej były podporządkowane i która była ich przeznaczeniem ${ }^{3}$. To w konsekwencji uniemożliwiło podporządkowanie życia ,jednostkom abstrakcyjnie mierzonego czasu, funkcjonalnej organizacji przestrzeni, pojmowanie własnego losu w kategoriach racjonalnego mikro-projektu” $\mathrm{i}$ utrzymanie „zbalansowanej diety: równowagi lęku i afirmacji, zgrozy i bezpieczeństwa"5.

Lęk, mimo że częstokroć łączy we wspólnotę, stał się doznaniem:

niemile widzianym, nieodpowiadającym nowym warunkom egzystencji, wstydliwym. To [...] w nowoczesnej antropologii jednostki i jej wewnętrznych alternatywach tkwi źródło „lęku przed lękiem”, źródło jego wyparcia ${ }^{6}$.

\footnotetext{
1 A. Kołodyński, Seans z wampirem, Warszawa 1986, s. 92.

2 A. Bielik-Robson, Inna nowoczesność. Pytania o współczesna formule duchowości, Kraków 2000, s. 350.

3 M. P. Markowski, Anatomia ciekawości, Kraków 1999, s. 57.

4 R. Nycz, O nowoczesności jako doświadczeniu. Uwagi na wstępie, [w:] Nowoczesność jako doświadczenie, red. R. Nycz, A. Zeidler-Janiszewska, Kraków 2006, s. 9-10.

5 A. Bielik-Robson, dz. cyt., s. 335.

6 Tamże, s. 347.
} 
Fobofobia (lęk przed lękiem) staje się „ciemnym rewersem najjaśniejszego mitu nowoczesności: mitu jednostki wolnej, swobodnej, zdolnej do nieograniczonej, indywidualnej autokreacji"7, odbierając człowiekowi jego „naturalna reakcję na otaczający go chaos: jego prawo do lęku"8. Wyparty lęk nie maleje, ale przeciwnie - jest coraz bardziej agresywny, stając się tym większy, im mniej znajduje możliwości, by się ujawnić. Według praw psychoanalizy konsekwencja wypartego dążenia jest coraz większe prawdopodobieństwo, że ujawni się ono w formie zastępczej ${ }^{9}$. Niekoniecznie jednak musi ona przybrać formę agresji. W sukurs przychodzi w tym przypadku materia horroru, odsłaniając swoją szczególna naturę i stając się podświadomym przywołaniem „doznania wygnanego przez nowoczesność - jako pozytywnego i niezbędnego aspektu naszej duchowości"10. W ten sposób radykalnie przekształca zalecenie ponowoczesnego fenomenologa Johna D. Caputo: „trzymaj oczy szeroko otwarte na okropności świata, ale pamiętaj: "nie wolno ci się bać"" ${ }^{11}$. Gatunek horroru sięga po pejoratywny nakaz: bój się i znajdź w tym przyjemność - „dla umysłowości przednowoczesnej wyobrażenie czystego koszmaru [...] staje się cudownie nieskończonym obszarem wolności"12. Reżyserzy (Hideo Nakata, Takashi Shimizu, Takashi Miike) ${ }^{13}$, inspirując się japońskim folklorem, stworzyli szereg postaci duchów (onryou, których jedynym celem istnienia jest zemsta) i umieścili je w „nowym świecie” - w scenerii współczesnych, dużych, tętniących życiem metropolii. Notabene, sa to kobiece "stare strachy" (Sadako, Mitsuko Kawai, Kayako Saeki, Mimiko Mizunuma), znajdujące się w chwili smierci pod wpływem potężnych emocji - miłości, zazdrości, nienawiści lub żalu i uwięzione wskutek tego w międzywymiarowej pułapce, $z$ której powracaja do świata żywych, żeby się na nich zemścić. Atutem szczególnym, zdecydowanie przyczyniającym się do popularności przywoływa-

7 Tamże, s. 348.

8 Tamże, s. s. 350.

9 Por. tamże, s. 348-349.

10 Tamże, s. 332.

11 Tamże, s. 338-339.

12 Tamże, s. 339.

13 Filmami, które będa punktem odniesienia dla moich rozważań, sa zrealizowane w ciagu dziesięciu lat (1998-2008) japońskie oryginały: Ringu (1998), Ringu 2 (1999), Honogurai mizu no soko kara (2002) H. Nakaty, Ju-on (2003), Ju-on 2 (2003) T. Shimizu, Chakushin ari (2003) T. Miike oraz ich amerykańskie „realizacje": The Ring (2002) G. Verbinsky'ego, The Ring 2 (2005) H. Nakaty, Dark Water. Fatum (2005) W. Selles'a, The Grudge - Klatwa (2004), Grudge - Klatwa 2 (2006) T. Shimizu, Nieodebrane połaczenie (2008) E. Valette'a. 
nych filmów, było posłużenie się przez twórców nowoczesnym medium, za pomoca którego negatywna energia mogła oddziaływać na żywych. W takim wypadku na sukces na rynku zagranicznym nie trzeba było czekać zbyt długo. Amerykanie zaczęli realizować ich remaki już w kilka lat po premierze oryginałów.

Oddziaływanie japońskich horrorów i ich amerykańskich odpowiedników odsłania esencję ludzkiej wolności, otwiera i oczysz$\mathrm{cza}^{14}$, nie pozwalajacc człowiekowi nowożytnemu oddawać się swej wolności „bezlękowo” - fearless ${ }^{15}$. Odpowiadając na bezradność postmodernistycznej refleksji nad kultura wobec nieskończoności potencjalnie możliwych splotów znaczen ${ }^{16}$, japońskie horrory, jak i ich amerykańskie realizacje (remaki) staja się soczewka skupiająca na nowo dwie najpopularniejsze płaszczyzny przyjemności wyróżnione przez Rolanda Barthesa (jouissance i plaisir) ${ }^{17}$ :

Jouissance to rozkosz, przyjemność ciała doświadczana poprzez zmysły, która wymyka się kulturowej i semiotycznej kontroli. Czerpana jest $z$ łamania kulturowych reguł i zasad, polega na zawieszeniu tożsamości społecznie tworzonej i kontrolowanej. Plaisir natomiast jest ulokowana w kulturze, w niej ma swoje źródło i jej regułami się kieruje ${ }^{18}$.

Jako że pierwsza $z$ nich jest przyjemnościa bezpośrednia, dopuszczająca żywiołowe, zaangażowane uczestnictwo w tekstach popkultury, wydaje się dominująca w przypadku oryginałów japońskich, będących dla widza na rynku europejskim i amerykańskim dużym zaskoczeniem i czymś w rodzaju zrealizowanego pożądania egzotyki/obcości. Podczas gdy ich amerykańskie remaki, przekładające już raz wykorzystane pomysły na inny grunt odbiorczy i kulturowy, uruchamiaja dyskursywną przyjemność plaisir, w której zadowolenie połaczone jest $z$ potwierdzeniem słuszności swojej alokacji w społecznej hierarchii gustu ${ }^{19}-\mathrm{w}$ tym wypadku w plaisir łączą się dwa zasadnicze elementy, związane $z$ zapożyczeniem/zaadaptowaniem: plaisir intellectuel (przyjemność intelektualna) i fait de posséder (fakt posiadania).

14 Por. A. Bielik-Robson, dz. cyt., s. 356.

15 Por. tamże, s. 358.

16 Por. K. Piatkowski, Opowiadać czy obrazować-ironiczne pytanie o dylemat antropologów schyłku tysiaclecia, [w:] Transformacja, ponowoczesność, wokół nas i $w$ nas, red. A. Paluch, Wrocław 1999, s. 37.

17 Por. M. Brzozowska, Przyjemności w Krainie Czarów, [w:] Kultura przyjemności. Rozważania kontrkulturowe, red. J. Grad, H. Mamzer, Poznań 2005, s. 92.

18 Tamże, s. 92.

19 Por. tamże, s. 92-93. 
Trudne jednak jest rozstrzyganie, gdzie tkwi początek i czy w ogóle nastapi kiedyś koniec tych wielokrotnie spiętrzonych adaptacyjnych procesów i transformacji. Niewiadoma jest również, co potencjalnie czeka nas jako widzów po przekształceniu społeczno-kulturowej rzeczywistości oryginalnego filmu przez remake i czy będzie to przyjemna czy przykra niespodzianka ${ }^{20}$. Film zostaje bowiem na nowo „przesłany” w inna przestrzeń kulturowa, a także na nowo w niej „zinterpretowany”.

Za element łączacy przywoływane horror story w ogniwa jednego łańcucha można przyjąc mechanizm społecznego odtwarzania „miejskiej legendy” i tym samym tworzenia jej nowych wariantów, co daje możliwość uchwycenia efektów społecznego replikowania legendy oraz działania masowych środków komunikacji jako źródeł i środków przekazu ${ }^{21}$. $Z$ pierwszym przywołaniem legendy mamy do czynienia już w początkowej scenie Ringu H. Nakaty - Masami Kurahashi opowiada swojej przyjaciółce Tomoko Oishi historię o niebezpiecznej kasecie:

Jeden chłopak pojechał na wakacje $z$ rodzina do Izu. Miał ochotę iść się bawić, ale w telewizji był program, którego nie chciał przegapić. Postanowił go nagrać. Ale wideo było inaczej ustawione niż u niego w domu. Ten kanał był pusty i nic nie powinno się było nagrać. Kiedy chłopak puścił taśmę, zobaczył na ekranie kobietę. Umrzesz za tydzień - mówiła. Chłopiec zatrzymał magnetowid i wtedy zadzwonił telefon. Widziałeś? - spytał głos. W tydzień później chłopak umarł.

Opowiedziana podczas beztroskiego wieczoru legenda znajduje swoje urzeczywistnienie w gwałtownej śmierci Tomoko. Co więcej, sama „plotka” zostaje uwierzytelniona i przekazana dalej przez mechanizm zapisu na taśmie wideo - Koichi Asakawa nagrywa w jednej ze szkół rozmowy $z$ nastolatkami na temat historii krążących o śmiercionośnej kasecie:

- Słyszałaś o tej „klątwie wideo”?

- Tak. [...] Na ekranie pojawia się jakaś przerażajaca kobieta i mówi, że za tydzień umrzesz. Ukazuje się tym, którzy oglądają nocny program.

A potem dzwoni telefon. [...]

- Czy naprawdę ktoś umarł w tydzień po obejrzeniu?

- Nikt, kogo byśmy znały.

- Co?

- Mój kolega mówił, że jedna, co widziała, umarła na randce ze swoim chłopakiem.

20 J. Kozielecki, Transgresja i kultura, Warszawa 1997, s. 51.

${ }^{21}$ Por. D. Czubala, Współczesne legendy miejskie, Katowice 1993, s. 26-27. 
Mechanizm powielania „miejskiej legendy” zostaje wpisany także w strategię dystrybucyjna „realnego” filmu. Po pierwsze, H. Nakata w wywiadzie zamieszczonym w dodatkach na płycie $z$ jednym $z$ horrorów opowiada o mającej miejsce po zakończonych seansach „spontanicznej” kampanii reklamowej:

Tak się składa, że zarówno w filmie, jak i w rzeczywistości pogłoski o zabójczym wideo narodziły się w tym samym miejscu, w małych barach, do których ludzie przychodza się napić i coś zjeść. Większość japońskich nastolatków ma telefony komórkowe. W dniu premiery Ringu odwiedziłem pięć czy sześć kin i w każdym $z$ nich po zakończeniu pokazu widziałem dzieciaki dzwoniace do siebie nawzajem z komórek i mówiące: „To naprawdę przerażający film, musisz koniecznie go zobaczyć!”. Ta spontaniczna kampania reklamowa wśród nastolatków bardzo mi się podobała.

Po drugie, dystrybutor zamiast standardowego komunikatu o ochronie praw autorskich zamieścił ostrzeżenie:

Dystrybutor filmu nie ponosi odpowiedzialności za jakiekolwiek urazy lub wypadki śmiertelne, które moga powstać w trakcie lub po obejrzeniu tego materiału wideo, włączajac w to wszelkie szkody fizyczne i psychiczne. Dystrybutor również nie bierze odpowiedzialności za elektroniczne i jakiekolwiek techniczne usterki, które moga wystąpić w efekcie odtwarzania tego materiału.

Wypełniające się przepowiednie i opowieści o nich sa wielokrotnie reprodukowane przez twórców w kolejnych horrorach oraz sequelach po obu stronach oceanu, wikłając się w labiryntowość miasta jako synteza „okropności” lub „lęków”. W pewnym momencie odtwarzana w nieskończoność taśma grozy przekształca się w nowoczesną ulicę, niekończącą się „taśmę asfaltu”, której bezmiar jest przyciagający i fascynujący przede wszystkim lub właśnie $z$ tego powodu ${ }^{22}$.

Ekran doskonale sprawdza się w roli nośnika grozy. Przeraża nas to, co niewiadome i w niedający się wyjaśnić sposób „zakłócające” naturalny bieg rzeczy. Japońskie „nowe-stare” kino grozy, a także jego „pokłosie” (amerykańskie remaki) jako medium strachu wykorzystują towarzyszacy transmisji szereg „zakłóceń” (śnieżenie, brak synchronizacji, bardzo wyraźnie widoczna ziarnistość itd.). Ekrany telewizyjne (potencjalne media dla śmiercionośnej kasety), podobnie jak replikowana postać Sadako (funkcjonująca w tekstach kultury

22 Por. H. Paetzold, Miasto jako labirynt. Walter Benjamin i nie tylko, [w:] Przestrzen, filozofia $i$ architektura. Osiem rozmów o poznawaniu, produkowaniu $i$ konsumowaniu przestrzeni, red. E. Rewers, Poznań 1999, s. 118. 
popularnej zarówno jako olśniewający pięknościa hermafrodyta - pierwowzór książkowy, budząca przerażenie kobieta czy wreszcie odrzucona przez swoją rodzinę dziewczynka), zdaja się nie tylko mnożyć w nieskończoność, lecz także ulegaja modyfikacjom wynikającym z postępu technicznego i niwelujacym dotychczasowe ograniczenia - kaseta VHS jest jedynie punktem wyjścia.

Znalezienie się w zasięgu przekazu ekranu, które dotąd było koniecznym warunkiem, zostaje zniwelowane przez przekształcenie w nośnik horroru telefonu komórkowego, jak ma to miejsce w przypadku filmu w reżyserii T. Miike Nieodebrane połaczenie i jego amerykańskiego remake'u w reżyserii Erica Vallete'a. Telefon komórkowy „całkowicie przecina smycz łącząca użytkownika $z$ pokojem”23. W otaczającym nas świecie

rzeczy podlegają wzmożonej semiozie, stają się znakami. Gwałtowna „przemijalność" rzeczy, które odchodza [...] albo przychodza (jak telefon komórkowy) w sposób „epidemiczny”, nadaje dynamiki współczesnemu dyskursowi kulturowemu. Za życia jednego pokolenia zmienia się co najmniej dwukrotnie świat przedmiotowy w wybranych dziedzinach (samochody, meble, telewizory, telefony) ${ }^{24}$,

idealnie wpisując się we wszechogarniający chaos komunikacyjny. Godząc się $z$ jego istnieniem, właściwie wszyscy już „opanowali i rozwinęli w praktyce sztukę "płynnego życia»: zaakceptowali poczucie dezorientacji, uodpornili się na zawroty głowy i przywykli do stanu oszołomienia"25.

Telefon komórkowy wniknął w naszą intymność, nie pozwalając właścicielowi na pożądaną przez niego samotność i zyskując bezpośredni akustyczny dostęp do skrzętnie chronionej domowej twierdzy ${ }^{26}$. Raz na zawsze został również zweryfikowany znaczeniowy zakres słów „prywatne” i „publiczne” 27 - obie sfery zaczynają się w nowy sposób nakładać i przenikać cyfrowa cielesnością w nasza prywatnośćc ${ }^{28}$. Wskutek szybkiego rozwoju technicznego tego me-

${ }^{23}$ P. Levinson, Telefon komórkowy. Jak zmienił świat najbardziej mobilny ze środków komunikacji, Warszawa 2006, s. 26.

${ }_{24}$ R. Sulima, Antropologia codzienności, Kraków 2000, s. 9.

25 Z. Bauman, Płynne życie, Kraków 2007, s. 9.

${ }^{26}$ Por. P. Levinson, Miękkie ostrze, czyli historia i przyszłość rewolucji informatycznej, Warszawa 2006, s. 120-121.

27 Por. M. Żakowski, Życie społeczne przedmiotów $w$ kulturze popularnej, [w:] Gadżety popkultury. Społeczne życie przedmiotów, red. W. Godzic, M. Żakowski, Warszawa 2007, s. 8.

28 Por. R. Sulima, Telefon komórkowy - busola codzienności, [w:] Gadżety popkultury..., s. 202. 
dium i szybkiego dotarcia do wszystkich warstw społecznych zniknęła sprzeczność między bezpośredniościa a mediami (immediate i media); stały się one jednym i tym samym ${ }^{29}$. Telefon komórkowy, umożliwiajac natychmiastowy odbiór, produkowanie - i to na dalekie odległości - realizuje wszelkie idee, impulsy i strategie kiełkujące w ludzkim umyśle ${ }^{30}$. W ten sposób odległość przestała mieć znaczenie:

Czasami wygląda na to, że istnieje jedynie po to, by można ja było zlikwidować, jakby przestrzeń ciagle zapraszała do tego, by ją zlekceważyć, obalić, zanegować. Przestrzeń przestała być przeszkoda - potrzeba tylko ułamka sekundy, by ją zdobyćc ${ }^{31}$.

Jako jedna $z$ tych realizacji można zinterpretować strategię budowania grozy w oparciu o materię oferowanej nam przez telefon komórkowy mobilnej „wideosfery” i „fonosfery”, metaforycznie wpisujacych się w obszar "widnokręgu” i "słuchokręgu”, uformowanych przez śmiercionośna kasetę ${ }^{32}$. Proces ten można potraktować jako egzemplifikację mechanizmu przechodzenia wytworów techniki ze sfery produkcji technicznej do sfery produkcji symbolicznej i ich sytuowania się tym samym w przestrzeniach kultury ${ }^{33}$, co uruchamia narzędzie pośredniczące w obcowaniu $z$ obiektami kultury (formującą się między medium a przekazem przestrzeń interfejsu) ${ }^{34}$.

Kamera w filmie T. Miike podąża za dźwiękiem, charakterystyczna melodia telefonu komórkowego, $z$ jednej strony wyróżniając się na tle komunikacyjnego chaosu, $z$ drugiej - w niego się wtapiajacc. W powszechnym odbiorze

dzwonek telefonu oznacza usilną prośbę, na która nie można nie zareagować. Każdy $z$ nas snuje jakieś marzenia - ma pragnienia, których spełnienie może zależeć właśnie od tego głosu po drugiej stronie linii telefonicznej ${ }^{35}$.

\footnotetext{
29 Por. P. Levinson, Telefon komórkowy..., s. 84.

30 Por. tamże, s. 78-79.

31 Z. Bauman, Globalizacja. I co z tego dla ludzi wynika, Warszawa 2000,
} s. 92 .

32 Por. R. Sulima, Telefon komórkowy..., s. 199.

33 Por. tamże, s. 200.

34 A. Tarkowski w swym artykule przybliża definicje interfejsu zaproponowane m.in. przez L. Johnsona i L. Manovicha. Por. A. Tarkowski, Komputer. Krótka historia wyobrażeń technokulturowych, [w:] Gadżety popkultury..., s. 318.

35 P. Levinson, Miękkie ostrze..., s. 121. 
Mimo że w przestrzeni publicznej odnosimy się do niego obojętnie, w filmie T. Miike dźwięk aparatu wywołuje charakterystyczny dreszcz. Przez krótką chwilę to cisza staje się

żywiołem différance, żywiołem, w którym dochodzi do tajemniczego ujawnienia się tego, co obce, a co nie może zapisać się na stałe w sposób w pełni wyartykułowany $[\ldots]^{36}$.

Skala mylności naszego rozpoznania jest wprost proporcjonalna do skali [...] operacji pojmania życia przez śmierć ${ }^{37}$.

Nagrana wiadomość nie jest niesprecyzowaną bliżej groźba, jak w przypadku śmiercionośnej kasety (zreszta można ją było zneutralizować przez pokazanie taśmy innej osobie), ale zawiera relację ze śmierci osoby, do której zostaje wysłana (ostatnie słowa, towarzyszace temu dźwięki). Odsłuchiwany komunikat momentami nabiera nawet charakteru frywolnego déjà- $v u^{38}$ (przykładowo, scena śmierci $\mathrm{w}$ windzie). W myśl zapotrzebowania na medialne relacje „na żywo" paradoksalnie można stwierdzić, że tym razem medium wyprzedziło mającą się wydarzyć tragedię. Sama śmierć zostaje kilkakrotnie odtworzona i powielona: Yoko wraz $z$ towarzyszaca jej Yumi najpierw słysza jej śmierć w nagranej wiadomości, wiadomość tę odsłuchują także ich znajomi. Wypadek obserwujemy zarówno $z$ perspektywy kamery, jak i odbieramy go $z$ perspektywy Yumi, która uczestniczy w śmierci przyjaciółki, rozmawiając $z$ nia przez telefon. W horrorze T. Miike bezpośredniość mediów nabiera charakteru obosiecznego miecza ${ }^{39}$, którego cios wymierzony jest w potencjalna ofiarę nawet w momencie „zakłócenia” najbardziej niewybaczalnego $z$ możliwych, a mianowicie wyłączenia aparatu przez użytkownika bądź całkowitej rezygnacji z usług operatora.

Aparat komórkowy nie tylko

stanowi urządzenie wejścia-wyjścia informacji ze środowiska zewnętrznego (przyjmujac formy mniej lub bardziej zintegrowane $z$ ciałem ludzkim), ale też [...] służy jako repozytorium obrazów, dźwięków, wreszcie jako rodzaj pamięci peryferycznej (w sensie fizycznym, mentalnym i metaforycznym $)^{40}$.

${ }^{36}$ T. Sławek, U-bywać. Człowiek, świat, przyjaźń $w$ twórczości Williama Blake'a, Katowice 2001, s. 45.

37 J. Baudrillard, Wymiana symboliczna i śmierć, Warszawa 2007, s. 114.

38 Por. tamże, s. 113-114.

39 Por. P. Levinson, Telefon komórkowy..., s. 83.

40 A. Maj, „Keitai”- marginalia jako sens komunikacji, „Kultura Współczesna” 2008, nr 4, s. 118. 
Jak zauważa Anna Maj, „komórka” jest „niepozorna, lecz wszechmocna; peryferyczna, lecz niezbędna; marginalna, lecz fundamentalna. Może to przerażać, ale można też tego nie dostrzec"41. Parafrazujac ostatnie zdanie przywoływanego passusu - w odniesieniu do horrorów (zarówno japońskiego oryginału, jak i amerykańskiego remake'u) to „musi” przerażać i to „trzeba” dostrzec. Co więcej, to „powinno” także pobudzać, w myśl idei epoki mediów elektronicznych jako epoki komunikacji „dotykowej” - koncepcji wysnutej i opracowanej w badaniach prowadzonych przez Marshalla McLuhana:

Z chwilą, gdy dotyk traci dla nas wartość czuciową i zmysłowa („dotyk jest współdziałaniem zmysłów, a nie zwyczajnym kontaktem skóry z przedmiotem"), pojawia się możliwość, że stanie się na powrót schematem komunikacji, tym razem jednak jako pole „taktylnej” i „taktycznej” symulacji, w którym przekaz (Messager) staje się „masażem” (massage), wszechobecną zachęta, nieustannym testem. Testowani, badani, dotykani i sprawdzani jesteśmy wszędzie i ciagle. Metoda zyskuje [...] charakter „taktyczny”, sfera komunikacji zaś - „taktylny”42.

\section{BibLIOGRAFIA}

Baudrillard J., Wymiana symboliczna i śmierć, tłum. Sławomir Królak, Warszawa 2007.

Bauman Z., Globalizacja. I co z tego dla ludzi wynika, tłum. Ewa Klekot, Warszawa 2000.

Bauman Z., Płynne życie, tłum. Tomasz Kunz, Kraków 2007.

Bielik-Robson A., Inna nowoczesność. Pytania o współczesna formułe duchowości, Kraków 2000.

Brzozowska M., Przyjemności w Krainie Czarów, [w:] Kultura przyjemności. Rozważania kontrkulturowe, red. J. Grad, H. Mamzer, Poznań 2005.

Czubala D., Współczesne legendy miejskie, Katowice 1993.

Kołodyński A., Seans z wampirem, Warszawa 1986.

Kozielecki J., Transgresja i kultura, Warszawa 1997.

Levinson P., Miękkie ostrze, czyli historia i przyszłość rewolucji informatycznej, Warszawa 2006.

Levinson P., Telefon komórkowy. Jak zmienił świat najbardziej mobilny ze środków komunikacji, Warszawa 2006.

Maj A., „Keitai” - marginalia jako sens komunikacji, „Kultura Współczesna” 2008, $\mathrm{nr} 4$.

Markowski M. P., Anatomia ciekawości, Kraków 1999.

Nycz R., O nowoczesności jako doświadczeniu. Uwagi na wstępie, [w:] Nowoczesność jako doświadczenie, red. R. Nycz, A. Zeidler-Janiszewska, Kraków 2006.

41 Tamże, s. 126.

42 J. Baudrillard, dz. cyt., s. 84. 
Paetzold H., Miasto jako labirynt. Walter Benjamin i nie tylko, [w:] Przestrzeń, filozofia $i$ architektura. Osiem rozmów o poznawaniu, produkowaniu i konsumowaniu przestrzeni, red. E. Rewers, Poznań 1999.

Piątkowski K., Opowiadać czy obrazować - ironiczne pytanie o dylemat antropologów schyłku tysiąclecia, [w:] Transformacja, ponowoczesność, wokót nas i w nas, red. A. Paluch, Wrocław 1999.

Sławek T., U-bywać. Człowiek, świat, przyjaźń w twórczości Williama Blake’a, Katowice 2001.

Sulima R., Antropologia codzienności, Kraków 2000.

Sulima R., Telefon komórkowy - busola codzienności, [w:] Gadżety popkultury. Społeczne życie przedmiotów, red. W. Godzic, M. Żakowski, Warszawa 2007.

Tarkowski A., Komputer. Krótka historia wyobrażen technokulturowych, [w:] Gadżety popkultury. Społeczne życie przedmiotów, red. W. Godzic, M. Żakowski, Warszawa 2007.

Żakowski M., Życie społeczne przedmiotów w kulturze popularnej, [w:] Gadżety popkultury. Społeczne życie przedmiotów, red. W. Godzic, M. Żakowski, Warszawa 2007.

\title{
Filmografia
}

The Ring: Krag, reż. H. Nakata, 1998.

Nieodebrane połaczenie, reż. T. Miike, 2003.

Nieodebrane połaczenie, reż. E. Vallete, 2008.

\begin{abstract}
Directors (Hideo Nakata, Takashi Shimizu, Takashi Miike), inspired by a Japanese folklore, created the row in the figure of ghosts (onryou, of which a revenge is a sole aim of the being) and put them in "new world" - in scenery of contemporary, big and lively metropolises. As part of the recalled horror story it is possible to compose the mechanism of reconstruction of the "urban legend" and the creation of new variants - it's conceivable that the capture effects of public replying the legend, action of mass means of communication as sources and media, as well bare the greatest taboo of the modernity fear of fear itself. In this article, author presents also how Japanese horror and their American implementations (remakes) are becoming a convergent lens, focused two popular basis of pleasure singled out by Barthes.
\end{abstract}

Key words: horror story, remake, urban legend. 